Artigo recebido em: 31/03/2018

Artigo aprovado em: 01/06/2018

\title{
VERDADE E METAFÍSICA
}

\author{
a filosofia de Nietzsche e a crise da religião
}

\author{
TRUTH AND METAPHYSICS
}

Nietzsche's philosophy and the crisis of religion

Giovane Martins Vaz dos Santos ${ }^{1}$

(giovane.martins1994@gmail.com)

\section{RESUMO}

Este trabalho pretende analisar a filosofia de Nietzsche especificamente no que tange ao conceito de "verdade". Para isso, ele será dividido em três partes: na primeira, analisaremos como Nietzsche definiu o conceito metafísico de verdade e faremos uma exposição sobre como esse conceito aparece na religião cristã; na segunda parte, trataremos especificamente do problema da verdade no contexto em que Nietzsche publicou seus trabalhos de crítica à religião e à metafísica; na terceira parte, exporemos como Nietzsche imaginava uma filosofia sem verdades metafísicas, ou seja, sem metafísica alguma com pretensão de validade universal.

Palavras-chave: Verdade; Filosofia da Religião; Cristianismo; Nietzsche; Niilismo.

\begin{abstract}
This work intends to analyze the philosophy of Nietzsche specifically regarding the concept of "truth". For this, it will be divided into three parts: in the first part, it will be analyzed how Nietzsche defined the metaphysical concept of truth and it will be exposed how this concept appears in the Christian religion; in the second part, it will be dealt specifically the problem of truth in the context in which Nietzsche published his works of critique of religion and metaphysics; in the third part, it will be exposed how Nietzsche imagined a philosophy without metaphysical truths, that is, without any metaphysics with pretension of universal validity.
\end{abstract}

Key words: Truth; Philosophy of Religion; Christianity; Nietzsche; Nihilism.

\section{Introdução}

\footnotetext{
${ }^{1}$ Mestrando em Filosofia pela Pontifícia Universidade Católica do Rio Grande do Sul (PUC-RS).

CV Lattes: http://lattes.cnpq.br/7332860443899976.
} 
A filosofia de Nietzsche é vista por diversos autores de manuais de filosofia como um pensamento de transição da modernidade para a filosofia contemporânea. De fato, Nietzsche foi um filósofo capaz de propor diversas ideias inovadoras em diversos campos da filosofia. Produziu uma interpretação original sobre a história da filosofia, com considerações singulares e instigantes; absorveu o espírito da sua época ao fazer diagnósticos e demonstrar, de forma alegórica, a crise de valores pela qual passava a cultura do século XIX; foi capaz de "prever" diversos problemas filosóficos que hoje são matéria de pesquisa da filosofia.

Uma das características mais marcantes da obra de Nietzsche diz respeito à crítica da religião e, mais especificamente, do cristianismo, que para o filósofo era uma consequência do platonismo. Essa crítica à religião cristã não é, como veremos, uma avaliação superficial da história do cristianismo, como se faz constantemente para "provar" que as instituições cristãs cometeram diversas atrocidades e, em seguida, fazer um julgamento de reprovação moral da religião. Tampouco é uma defesa do ateísmo. Não há, em Nietzsche, uma negação metafísica da existência de Deus. Não há apelo a provas lógicas ou ontológicas, nem qualquer argumento cientificista. O próprio cientificismo foi criticado pelo filósofo como uma espécie de pensamento religioso (CRISTY, 2018).

A crítica de Nietzsche ao cristianismo, ao contrário, é parte de todo um pensamento filosófico ligado aos problemas culturais da sociedade contemporânea a ele. O cristianismo é criticado dentro de um contexto maior que envolve a criação do pensamento metafísico na Grécia Antiga, sendo que este acabou influenciando o cristianismo e, por consequência, o pensamento moral e o senso comum dos séculos posteriores à criação da Igreja Católica como instituição religiosa e política.

Um dos problemas trabalhados por Nietzsche foi o da visão metafísica da Verdade, presente na religião como dado sagrado e, na metafísica, como campo de estudos. O conceito metafísico de "verdade" exerceu influência em praticamente todas as áreas de estudo, como a ciência, a religião, a filosofia e a política.

\section{O conceito de 'verdade' no cristianismo e na metafisica}

A metafísica ocidental, segundo Nietzsche, é fundada na ideia platonista de que o acesso à verdade está além do mundo terreno, fora do mundo sensível. Desse 
modo, o homem deve se esforçar para alcançar dois objetivos: o primeiro é acessar, através da Alma - o âmbito inteligível e não sensível -, as verdades do mundo das ideias; o segundo é viver de modo que a Alma se eleve em relação ao corpo, não sendo determinada por ele e evitando a influência das paixões.

Para que o primeiro objetivo seja alcançado é necessário que o segundo seja cumprido, isto é, para que a Alma seja astuta o suficiente para chegar ao conhecimento das Formas, é necessário viver de modo que a própria vida seja voltada para o mundo inteligível, evitando as inclinações das paixões e examinando-se constantemente. Desse modo, o conhecimento das Formas, das coisas em si, acabaria surgindo como lembrança - pois a Alma já havia passado pelo Mundo das Formas anteriormente. O detalhe é que na teoria platônica do mundo das ideias os dois objetivos anteriores servem para um terceiro e principal objetivo: o alcance, após a morte do corpo, do Mundo das Formas, de modo que a Alma não precise mais retornar ao mundo sensível, que serve somente como uma transição.

A teoria platônica do Mundo das Ideias é, para Nietzsche, a principal base do cristianismo. A leitura de Santo Agostinho, por exemplo, seria capaz de nos indicar diversos temas do neoplatonismo, a que o filósofo de Hipona teve acesso, presentes no contexto dos problemas filosóficos do cristianismo.

De fato, no mundo cristão a verdade também surge como uma entidade metafísica cujo acesso depende de um determinado modo de vida, guiado pela razão, que busque a vida eterna após a morte. A filosofia cristã não usa de termos iguais aos termos utilizados por Platão e pelos neoplatonistas, como "Mundo das Ideias" e "Mundo das Formas", mas outros termos, com caráter religioso e sentido filosófico semelhantes aos do platonismo, como "Eternidade" e "imortalidade da alma".

Segundo Nietzsche, o cristianismo realiza a mesma oposição platonista entre "mundo sensível" e "mundo inteligível"; no entanto, apenas o cristianismo, como qualquer outra religião, impõe um conjunto de regras para que o cristão alcance a vida eterna. Essas regras são, antes de tudo, códigos morais que o fiel deve seguir para que viva em relação a Deus, evitando, assim, ser consumido pelas tentações e inclinações do mundo sensível.

A visão metafísica da verdade criou diversos problemas que Nietzsche aborda ao longo das suas obras. Todos esses problemas partem da ideia de que as instituições cristãs chegaram ao conhecimento metafísico da Verdade e que, portanto, toda a humanidade deve viver de acordo com o recomendado por essas instituições.

O problema do niilismo, por exemplo, surge a partir do momento em que se aceita como verdade a ideia de que existe uma divisão de mundos e que, para se 
chegar à imortalidade, ou eternidade, é necessário seguir um conjunto de regras que tiram o ser humano do mundo sensível e o colocam no mundo inteligível. Isso faz do mundo terreno um grande vazio, faz da existência uma mera transição em nome da promessa de um mundo Bom, Perfeito, Eterno etc.

Com o desenvolvimento científico na Idade Moderna, a metafísica cristã começou a perder força e a ciência passou a disputar espaço com a metafísica. Na sequência, faremos uma análise da crítica de Nietzsche à filosofia moderna.

\section{Nietzsche e a 'verdade' na filosofia moderna}

A modernidade trouxe alguns pensadores que passaram a questionar as ideias metafísicas centrais do cristianismo. Nem por isso a metafísica foi deixada de lado. Um exemplo é a metafísica implícita nas obras dos grandes filósofos contratualistas do período, como John Locke, Thomas Hobbes e Rousseau, que fizeram filosofia política a partir de concepções metafísicas do homem e da natureza da sociedade. No entanto, filósofos como Descartes e Kant passaram a filosofar com base no método científico, que começava a ganhar mais importância na explicação dos fenômenos naturais.

Nietzsche vê na modernidade uma espécie de antagonismo: ao mesmo tempo em que o cristianismo perde força como religião por conta dos avanços científicos, a moral cristã permanece entranhada no pensamento do senso comum. Esse antagonismo torna o cristão um sujeito profundamente contraditório em suas práticas, pois a religião, não possuindo mais o valor de outrora, passa a ser vista como uma espécie de investimento religioso: a compra de um terreno no céu custa a abdicação da vida terrena. Não obstante essa visão mercadológica do Divino, a própria intenção de alcançar a vida eterna mostra uma grande vaidade e atribuição de importância em relação ao que, para Nietzsche, há de mais sensível e terreno: a vida.

A partir dessa interpretação, obviamente resumida para os nossos objetivos, Nietzsche declara a sociedade de sua época como "tomada pelo niilismo" e a consequente "morte de Deus". O niilismo, ou seja, o esvaziamento dos valores, é a causa da morte de Deus. Nietzsche declara que Deus morreu em um sentido alegórico e metafórico:

O homem Louco. - Não ouviram falar daquele homem louco que em plena manhã acendeu uma lanterna e correu ao mercado, e pôs-se a 
gritar incessantemente: "Procuro Deus! Procuro Deus!"? - E como lá se encontrassem muitos daqueles que não criam em Deus, ele despertou com isso uma grande gargalhada. Então ele está perdido? Perguntou um deles. Ele se perdeu como uma criança? Disse um outro. Está se escondendo? Ele tem medo de nós? Embarcou num navio? Emigrou? - gritavam e riam uns para os outros. O homem louco se lançou para o meio deles e trespassou-os com seu olhar. "Para onde foi Deus?", gritou ele, "já lhes direi! Nós os matamos - vocês e eu. Somos todos seus assassinos! [...]”. (NIETZCHE, 2012, Aforismo 125).

Quem declara a morte de Deus, portanto, não é Nietzsche, mas sim o Louco (representado por Diógenes, que, segundo Platão, foi "Sócrates tornado louco"). Nietzsche é apenas o seu porta voz. Mas por que somos nós os responsáveis pela morte de Deus?

O aforismo que declara a morte de Deus serve como diagnóstico dos tempos de Nietzsche e como sinal de que a humanidade deveria seguir novos caminhos no futuro. "Deus está morto" significa a morte dos valores absolutos que regiam a humanidade durante a maior parte da história do Ocidente, a falência da metafísica como motor da vida terrena. Nós matamos Deus porque fomos nós que criamos a ciência, o mercado, o entretenimento etc. A humanidade foi a responsável por trazer os valores absolutos, e com isso Deus, para a Terra, tornando esses valores mortos - embora ainda fosse "cedo demais" para que a humanidade percebesse a morte deles.

A verdade metafísica, portanto, acaba morrendo com os outros valores que regiam a humanidade. Não podemos mais ser guiados por uma Verdade que nos conduz ao nada; devemos ser guiados, agora, por nós mesmos. A última etapa da filosofia nietzschiana é propor um caminho para que o homem valorize somente o mundo em que está, sem apelar para a metafísica ou para o absoluto.

\section{3. "A verdade é feminina"}

No prefácio da célebre obra Além do Bem e do Mal, Nietzsche começa com a seguinte frase: "Supondo-se que a verdade seja feminina - e não é fundada a suspeita de que todos os filósofos, enquanto dogmáticos, entendem pouco de mulheres? (NIETZSCHE, 2001)”. Ao comparar a verdade com a figura feminina e, em seguida, declarar que todos os filósofos são dogmáticos e que, portanto, entendem pouco de mulheres, Nietzsche dá os primeiros passos, de forma metafórica, em sua teoria do perspectivismo. 
Ao comparar o conceito de verdade com a mulher, quais características Nietzsche quer atribuir à Verdade? Ora, como a mulher, a verdade não poderia ser abordada sempre da mesma forma, ou acabaríamos sendo rejeitados. Os filósofos, que na percepção de Nietzsche sempre foram dogmáticos, ou seja, fizeram filosofia seguindo suas próprias concepções metafísicas sem questioná-las, "entendem pouco de mulheres", isto é, entendem pouco do tema da verdade. Mas se a verdade é como uma mulher, como ela deve ser abordada?

Ora, se abordarmos a mulher sempre da mesma forma, não conseguiremos conquistála; do mesmo modo, a verdade escapa de nossas mãos quando tentamos transformá-la em um ponto absoluto. Logo, devemos abordar a verdade caso a caso, atentando para as particularidades do contexto e levando em conta a visão que temos a partir de nossa própria perspectiva.

O perspectivismo, baseado nessa ideia de verdade não metafísica, é a teoria que Nietzsche considerava necessária para que os filósofos do futuro pensassem de modo não metafísico e para que o niilismo fosse superado. Isso faria com que a humanidade caminhasse com as próprias pernas e acabaria com a visão metafísica que leva os filósofos ao dogmatismo. A própria frase "não há fatos, somente interpretações" indica que o caminho a ser seguido é o embate de interpretações a partir de diferentes perspectivas, sem o apelo a respostas metafísicas.

\section{Conclusão}

Nietzsche foi um filósofo inovador em diversos sentidos, e ainda contribui para a renovação de diversos debates filosóficos contemporâneos. No que se refere à verdade, nossa exposição mostrou como o filósofo alemão interpretou a história da filosofia a partir da ideia central do platonismo, que influenciou as principais ideias do cristianismo e perpetuou o dualismo mundo sensível versus mundo inteligível.

A filosofia moderna, por sua vez, não supera totalmente a metafísica cristã - Nietzsche vê nesse ponto a derrocada dos ideais cristãos e, ao mesmo tempo, a permanência deles no senso comum, provocando um vazio de valores que Nietzsche chama de "niilismo". Após "destruir" os valores platônicos e cristãos e invertê-los, trazendo todos os valores para a mão dos humanos, Nietzsche propõe a criação de novos valores, completando o ciclo de superação dos valores tradicionais. 
Poderíamos nos arriscar a dizer que a tarefa de Nietzsche de "transvalorar os valores" deu certo, em determinada medida. A filosofia contemporânea sofre várias influências do pensamento nietzschiano, mas essas influências não significam a adoção de suas ideias. Nietzsche é criticado e ao mesmo tempo "aproveitado" por diversas correntes filosóficas, como o neopragmatismo americano, que adotou a visão perspectivista de verdade e denomina todos os fatos "descrições" - algo muito próximo, senão mesmo um sinônimo, de "interpretações".

Porém, o fato de Nietzsche buscar a destruição dos valores metafísicos não implica um ateísmo. Nietzsche não busca afirmar ou negar a existência de Deus - o que por si só seria uma tarefa metafísica -, mas mostrar como os valores que considerávamos absolutos não servem mais para guiar a humanidade. 
Referências

CRISTY, Rachel. The Will to Truth and the Will to Believe: Friedrich Nietzsche and William James Against Scientism. 2018. Tese (Doutorado) - Philosophy, Department Of Philosophy, Princeton University, Princeton, 2018.

GHIRALDELLI JR., Paulo. O que é a morte de Deus e o niilismo. Disponível em: < http://ghiraldelli.pro.br/o-que-e-morte-de-deus-e-o-niilismo/>. Acesso em: 22 maio 2016.

GIACÓIA JUNIOR, Oswaldo. Nietzsche. São Paulo: Publifolha, 2000.

NIETZSCHE, Friedrich. A Gaia Ciência. São Paulo: Companhia das Letras, 2012. Tradução, notas e posfácio de Paulo César de Souza.

NIETZSCHE, Friedrich. Além do Bem e do Mal: Prelúdio de uma filosofia do futuro. São Paulo: Hemus, 2001. Tradução de Márcio Pugliesi. 2012a.

NIETZSCHE, Frieddrich. Assim Falava Zaratustra. São Paulo: Companhia das Letras,

MARTON, Scarlett. Nietzsche: Das Forças Cósmicas aos Valores Humanos. São Paulo: Brasiliense, 1990.

PLATÃO. A República. São Paulo: Martin Claret, 2012. 